\title{
Juries in serious fraud trials
}

\author{
by John Hansen
}

\author{
Four alternatives to trial by jury for serious fraud trials have been presented in a Home \\ Office consultation paper. John Hansen outlines the advantages and disadvantages of \\ these suggestions.
}

$\mathrm{T}$ he upsurge of business and economic globalisation and the bewildering speed of recent advances in technology have made business, and the litigation associated with it, much more complex as we approach the millennium. An offshoot of this has been that fraud trials have became more complex and inevitably have taken longer. In virtually every jurisdiction, where such cases have been heard by juries, concerns have been expressed at the sheer length of the trials, their complexity and the ability of juries to cope adequately with the issues that have arisen. Every jury jurisdiction has struggled with how to deal with these problems.

In the UK the suggested responses to these difficulties can be found in the Home Office consultation paper Juries In Serious Fraud Trials. The paper puts forward four separate options as alternatives to the present form of jury trial. Retention of the status quo does not appear to be an option.

These options are suggested ways of trying those fraud cases that are described in the paper as 'serious fraud trials'. The paper discusses ways of identifying serious fraud trials and it is clear the term will encompass all cases transferred under s. 4 of the Criminal Justice Act 1987 and any other cases where a preparatory hearing has been ordered under s. 7 of the same Act. The decision as to whether or not a case should be treated as serious fraud will ultimately be for the trial judge, based on the overriding criterion of the 'interests of justice'. The judge will also be required to take into account the following factors:

(1) whether the case requires some specialised knowledge;

(2) whether the factual issues are complex or voluminous;

(3) whether prolonged examination of documents or accounts would be involved;

(4) whether the trial, as a whole, would be unduly long or complex.

There is intended to be an interlocutory right of appeal against the decision that a case is to be heard by the alternative method. Following that, the mode of trial will be specifically excluded from the possible grounds of appeal against any subsequent verdict.

\section{SPECIAL JURY}

The first of the four options is that the trial be heard in front of a special jury. Special juries are not new; in the past they were the same size as a common jury but the jurors had the status of 'banker, merchant or esquire'. What is now suggested is a more sophisticated screening process. The paper mentions possible disadvantages, chief of which will be the elitist nature of this special jury. That was one of the reasons for abandoning special juries previously. A further serious disadvantage will be whether sufficient jurors will be available. In my own experience in New
Zealand, there appear to be few professionally qualified persons on juries. Those that are selected are often retired or from professions that would give them no particular skills in relation to serious fraud matters. Whatever the reason, professionals seem to be more able than most to avoid jury service.

\section{JUDGE SITTING ALONE}

The second option is for a judge sitting alone. The paper actually uses the term 'experienced judge' but does not elaborate. It is unclear whether this envisages the somewhat invidious process of selecting certain criminal judges to hear serious fraud trials. If this is envisaged, it carries its own particular set of problems, not least of which is who selects the judges. It would seem unlikely that such a course would find favour with the defence bar. There is also an option of a pancl of judges, but this would appear to be something quite radical in a common law jurisdiction. There are also difficulties with majority decisions and, in most jurisdictions, there are already too few judges to go round.

Mention is made of the right in New Zealand for the defendant to elect for trial by judge alone. This is provided for in s. $361 \mathrm{~B}$ and $361 \mathrm{C}$ of the Crimes Act 1961. It is not limited to fraud cases, but it is available for all offences where the maximum penalty is less than 14 years' imprisonment. The largest and most significant fraud trial in New Zealand was conducted before a judge alone at the request of the numerous defendants. It involved copious documents and electronic data. Anecdotal evidence suggests that the trial was dramatically shortened by being heard by judge alone. The decision was handed down expeditiously and the ultimate appeals, that went as far as the Privy Council, were unsuccessful.

The authors of the discussion paper are concerned that the option remains with the defendant, but at least that would answer what will be obvious concerns from the defence bar. What the New Zealand experience does show is that, even in the most serious and complicated fraud trials, defendants will elect this option. It is certainly worth considering.

Profile of the author

John Hansen was profiled in Issue 6 of Amicus Curiae, when he explained some of the approaches to judicial reform in his home country to Julian Harris.

\section{FRAUD TRIAL TRIBUNAL}

The third option contemplates the creation of a fraud trial tribunal. This would consist of a judge and suitably qualified lay members. Reference is made to the Financial Services Tribunal as a guide to how such a tribunal would function. However that 
body, while considering fraud and other serious matters in the context of individuals faced with disqualification from employment in the financial services industry, is not determining criminal guilt. Judges sitting with experts are not uncommon in the civil jurisdictions of common law courts, but in criminal jurisdiction it is quite a radical step.

\section{JUDGE WITH JURY LATER}

It is the fourth option discussed that is perhaps the most unusual and marks the most radical departure from our accepted concepts of criminal law and the respective functions of judge and jury. This is described as trial by a single judge with a jury for key decisions. It is envisaged that the trial would have three broad stages. The first would consist of the judge identifying the issues. The authors consider this would shorten the process, because it would prevent the need for pre-trial evidential rulings, as the second stage would consist of the judge making determinations of fact. At this second stage the judge would deal with the factual issues; the authors equate this to the present summing-up, but it is obviously far more than this. The judge would make findings of fact but would not determine guilt. The final stage would consist of the jury being sworn in and the judge then explaining the case to them. The jury would then be asked to determine whether the conduct amounted to dishonesty or whether inferences could be drawn that a defendant had requisite knowledge or had behaved recklessly.

The extreme difficulties of this unusual approach are highlighted in the paper which acknowledges that the judge's finding on the factual issues may need to be supplemented by evidence from the defendants explaining themselves, or even additional evidence from key witnesses! It would appear likely that this alternative will be the least likely to receive support.

In the New Law Journal, 20 February 1998, Robert Rhodes QC deplored the suggestion of doing away with jury trials for serious fraud. His article contains trenchant criticisms of the proposals in the Home Office consultation paper. However, serious fraud trials do create problems of length and size and it is proper that those difficulties be debated. It is to be hoped though, that such a fundamental change as denying the right to jury trial would only come about from reasoned debate with full regard to the rights of defendants. It would be wrong if it came about because of certain well-publicised, unsuccessful prosecutions.

There is the added danger that it could be the thin end of the wedge. Very complicated evidence can arise in other areas as well. In New Zealand there was a highly publicised attempted murder trial. It was an allegation of poisoning against a jilted lover. Both parties were academics and the victim enjoyed a worldwide reputation in his field. The poison allegedly used was extremely rare. Experts from around the world gave evidence for prosecution and defence. The nature of their evidence was extremely complex, probably more so than that given in most complex fraud trials. Should cases such as this have some special procedure? Why should a special procedure apply only to fraud cases with complex evidence and not to other criminal charges with equally complex evidence? These are critical questions that need to be examined with very great care before something as fundamental as the right to trial by jury is lost.
John Hansen

Mr Justice Hansen, Executive High Court Judge, New Zealand

\title{
The best way forward in fraud trials?
}

\author{
by Christopher W Dickson
}

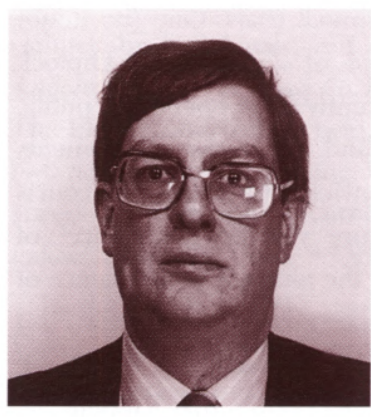

Much could be done to improve existing jury trials, believes Christopher Dickson, who looks at the background to the consultation document on the future of juries in serious fraud trials, and discusses the possible outcome.

$\mathrm{T}$ he recent Home Office consultation document on the future of juries in serious fraud trials has been characterised by some as an attempt to ensure that the high profile Serious Fraud Office defeats of the past are not repeated in the future. I do not believe that this is its purpose. Contrary to popular perception the Serious Fraud Office's record is a good one: most recently a $94.4 \%$ conviction rate since April 1997, with a 'lifetime' rate of over 70\%. It is a record which stands comparison with those of comparable prosecutors anywhere, reflecting as it does some of the most difficult and complex criminal cases ever tried. I do not believe it would have been significantly different, taken over the last ten years, whatever alternative mode of trial had been in operation.

What is really behind the Home Office document is a desire 